\title{
Potatoes Tuberous Reproduction Productivity Dependence On Seedlings Growing Technique
}

\author{
S. A. Filippova, L.V. Eliseeva, G.A. Mefodiev, L. G. Shashkarov \\ Department of Agriculture and Plant \\ Chuvash State Agricultural Academy \\ Cheboksary, Russia \\ svetlanka_631980@mail.ru
}

\begin{abstract}
The analysis of various methods of obtaining potatoes seedlings was conducted. The study objects were the first and second tuberous reproduction of the hybrid generative progeny of the Nikulinsky and Breeze varieties. The aerial portion of potato plants was estimated by their height. The yield structure analysis during harvesting was determined by the total number of tubers, the mass of tubers - from the bush, yield and marketability. The transplanting method of obtaining seedlings of potato plants from seedless one is characterized by an increase in yield structure indicators and an increase in the yield of tubers. There is a decrease in all the studied quality indicators in the second tuberous reproduction in comparison with the first one. The highest yield was obtained in the variant with the transplanting method of obtaining seedlings, and superiority is observed throughout the entire period of research. The average increase in the tuber yield of the first tuber reproduction in the experimental variant was $4.8 \mathrm{t} / \mathrm{ha}$.

The marketed product yield in the first tuberous reproduction, obtained by the transplanting method of growing seedlings, was $\mathbf{7 7 \%}$ for an average of three years, which is $\mathbf{7 \%}$ above control. The increase in the second tuberous reproduction also amounted to $7 \%$.
\end{abstract}

Keywords - potatoes, tuberous reproduction, seedlings

\section{INTRODUCTION}

A promising direction for the development of potato seed production today is generative reproduction. In contrast to the original seed development, based on the production of seed material by the method of meristem culture, this method of obtaining a healthy planting material is cheaper and simpler [1]. Moreover, in this case, the period of seed material production is reduced to two years, which is most preferable in our conditions. The nursery of seedlings becomes the first link of such system [2].

Potatoes are usually grown from tubers. An average of 3.03.5 tons of seed material is spent per hectare. And this in turn leads to an increase in total costs from 50 to $55 \%$. In the case of potato cultivation with generative seeds, about $60 \mathrm{~g}$ of seeds are spent per hectare. In addition, the multiplication of potatoes by planting botanical seeds promotes the healing of seed material from a viral infection, because viral diseases are not transmitted through the seeds to the next generation. This allows getting healthy raw potato material. Potato tubers obtained by this method can be used as seed material for up to 3 reproductions, which, in turn, is economically justified and efficient [3].

Plant selection breeders involved in the study of obtaining seed material of potato from true seeds, managed to maintain sufficient genetic variation of the most important traits that are crucial in the production of this crop. This was achieved by adding new sources of variation to the original population [4].

The environment has a significant impact on the physiological factors that determine the quality of seed potato material. When it comes to true potato seeds (TPS), this question is particularly relevant. Indeed, in order to evaluate the technology for the production of seed potato material from TPS, it is necessary to obtain reliable data on the high quality of the resulting seeds. The conditions for the production of tubers and the production of high-quality TPS do not always coincide. Everyone knows that the main indicator of the seed potato material quality is germination energy, since it depends on its germination under adverse environmental conditions. The use of increased doses of nitrogen in potato seed production is used to increase seed germination energy. The disadvantage of the TPS technology is a reduction in the germination energy of the seed material obtained this way. However, many scientists believe that a significant improvement in TPS technology can be achieved using agrotechnological techniques that affect the physiological factors of obtaining high-quality seeds. Up to date, research directions have already been identified; they are aimed at developing methods for producing TPS with optimal gene expression.

Tuber is the end product of potato evolution with the aim of survival of the species in conditions of limited resources. However, seed material obtained from TPS also increases the chances of survival of the species in adverse conditions. The difficulty of this technology lies in the fact that seeds grown in ideal conditions have a low potential for obtaining high yields. However, many researchers have found that seedlings of late ripening potato varieties show excellent germination energy in various soil and climatic conditions [5]. 
In developing countries, TPS technology, based on the use of seedlings as a seed material, is being introduced by farmers in agricultural production.

The process of transition from vegetative propagation of potatoes to generative has not been sufficiently studied and requires careful evaluation of modern methods for the production of potato seedlings using TPS technology. However, the technology of seed material production using seedlings can be considered as an alternative to traditional potato production [6].

True potato seed (TPS) technology is based on the use of the reproductive seed, also called botanical seed, true seed, or simply seed. Also, the term TPS is often used as a synonym for potato plant seeds. TPS is considered an alternative to seed or table potatoes in relation to seed material in the form of tubers. TPS technology is based on the production of seedlings, subsequently sown in field conditions. A potato seed obtained using TPS technology is enough to produce mini-tubers, which is enough to plant on an area of 1 ha. It is possible to produce both seed material and potatoes intended for table purposes from the resulting seedlings. The soil must be well prepared for transplanting seedlings to open ground. It is desirable to use drip watering or other irrigation systems, which will increase the percentage of survivability of seedlings. In order to plant seedlings with an area of 1 hectare, it is enough to get 100 grams of TPS seeds [7].

TPS varieties are derived from crosses between selected ones, but the variability of both the tubers and the plants can be observed by heterozygous parents in subsequent generations. For this reason, the tubers obtained from the TPS varieties in each subsequent generation should be selected according to the best characteristics in order to increase the yield and quality of the products obtained.

The production technology of hybrid TPS is based on the use of male sterility, which minimizes the cost of hybridization. Management of maternal plants of potatoes is used in order to increase seed production. From 100 to $150 \mathrm{~kg}$ of TPS can be produced per hectare. TPS seeds are able to maintain their germination for a long time. In order to remove seeds from dormancy, they are processed by high temperatures for 4-6 months or hormonal preparations are used.

The growth and development of transplanting seedlings of potatoes depend on the speed of development of the root system, since there is a maximum need for moisture and nutrients in the early stages of their development.

The physiology of seedlings has an effect on the length of the growing season of plants - it increases in comparison with the tuber plantings. In addition, the size of the obtained tubers decreases and the number of them grows up.

TPS potato seed material technology is an alternative for small farmers producing this crop. The advantages of TPS seedlings over seed tubers have aroused the interest of many potato producers.
The main advantages of TPS are their relative cheapness, ease of transportation due to the minimum volume, ease of storage, since they do not require harsh conditions and large areas. In addition, TPS seeds remain viable for several years and can be sown at any time. If conditions are met - the temperature of $4-10^{\circ} \mathrm{C}$ and humidity of $3-5 \%$ - germination of TPS seeds lasts up to 8-10 years. For manufacturers, it is of particular interest that TPS seeds are obviously healthy and free from infection by pathogens, since most harmful pathogens are not transmitted by TPS. The term for obtaining TPS seed material is much less than that of clonal propagation of tubers. So two seasons are necessary for the production of 50,000 mini-tubes. The first one starts with obtaining $20 \mathrm{~g}$ of TPS from three mother plants, whereas this requires 4 to 5 seasons with clonal multiplication of potatoes [8].

Since the TPS economy is not able to compete with seed material in the form of tubers, this technology is relevant for areas in which seed tubers are an expensive material with poor quality. The TPS technology is relevant for the restoration of the traditional seed system after natural disasters, as well as to ensure food security in a number of developing countries [9].

Agricultural producers who prefer this technology will have to face a number of difficulties. Since potato seeds are quite small, and transplant of seedlings is quite tender, the production process requires certain skills. Young seedlings are highly susceptible to the negative impact of soil and climatic conditions - hence there is a great risk of crop failure and the loss of tender seedlings. For this reason, this technology is not recommended for the production of marketable potatoes. Improving the efficiency of potato production using the TPS technology is possible when developing mechanized cultivation technology. Studies in this direction are already underway [10].

Until now, due to genetic difficulties, hybrid potato seeds have practically not been used in the production of seed material. Tubers were thought to be the simplest option for obtaining seeds. However, the TPS technology allows one to overcome the potato yield barrier, which makes the technology for obtaining seed material using botanical seeds, actual and promising.

Hybrid potatoes will play a key role in the sustainable development of the agro-industrial complex in the coming decades. This will happen thanks to the possibility of mass production of high-quality virus-free potatoes, with which it is possible to feed the people living on earth. TPS technology has enormous potential in improving the cultivation of potatoes.

The main advantage of TPS technology is the possibility of selecting plants with certain combinations of genes and their further reproduction through seeds in the form of clones. The weighty difference of this technology lies in the fact that this process does not require expensive tissue cultures as for in vitro clonal micropropagation [11]. 
Plant selection breeders in many countries of the world are inclined to believe that TPS will be a real revolutionary breakthrough in the agricultural sector in such an important crop as potatoes. The value of this technology is equated to the value of the "green revolution", especially for the third world countries. All this speaks of the technical feasibility, economic justifiability and scientific validation of the TPS technology. In addition, this technology is environmentally friendly, which is especially important in organic farming [12].

Many potato breeders have noted the advantages of using botanical seeds (TPS) to obtain high-quality seed material over traditional tuber use technology. An obstacle to the development of this technology is that research is not conducted in all countries and conditions. In this regard, it is difficult for scientists to determine the factors affecting the viability of this technology. The International Potato Center (CIP) began to seriously study this issue in the 1970s. The first experiments on TPS technology were carried out in 1977. Similar studies were conducted in more than 34 countries already by 1984 . The experiment also involved farmers from 5 states.

Two variants of TPS research were carried out in parallel obtaining seedlings from botanical seeds by direct sowing and obtaining seedlings in nurseries with their subsequent planting in the field.

Seedlings are grown in two main ways: Transplanting and field-seeded. The field-seeded method involves sowing seeds directly in the field, whereas 40-50 days old seedlings obtained under greenhouse conditions are planted in the field in the transplanting method [2].

Researchers had to face the problem of increasing the vegetation period due to the fact that it took time for seed to germinate. Sometimes the vegetation period is 30 days longer than the growing season of plants derived from potato tubers. Seed germination was not high; the growth of seedlings in the initial stages of development was rather slow. The option of using ready seedlings in this case is considered as an alternative. However, the difficulties were waiting for researchers here. The seedlings turned out to be sensitive to the process of planting in field conditions, where it is quite difficult to create controlled conditions. The leaves of potato plants, obtained from seedlings, turned out to be more attractive to aphids, the main carrier of the virus infection of potatoes. Therefore, potatoes grown from seeds turned out to be more susceptible to viral and viroid infections than plants derived from tubers [13].

The positive results from experiments on TPS technology have attracted the attention of scientists from many countries [9].

TPS technology has become widespread in China. There is information that farmers in China planted about 15,000 hectares of tubers obtained from TPS seeds in the 1960s. The technology was aimed at addressing the issue of seed material quality in relation to viral diseases. Up to date, the TPS technology has evolved from a temporary source of seed material production into a stably functioning system of potato seed production [14].

The idea of obtaining potato seed material from TPS seeds originated in Peru for a good reason. This was due to the fact that the climatic conditions of the territory did not allow to produce high-quality planting material of potatoes in the form of tubers. The 1995 flood contributed to the proliferation of TPS as a way to quickly restore the potato seed system [15].

The cost of potato seed tubers is very high in India. Therefore, TPS seeds are ubiquitous. The area under TPS seeds is about 1,500 hectares in the state of India alone. According to the national program for the development of seed production, the number of TPS is increasing annually; $158 \mathrm{~kg}$ of seeds were planted in 2004 .

TPS technology has aroused particular interest in Bangladesh from the very beginning - not all farmers could afford expensive seed material from Holland. High prices for potato seed material in the form of tubers led to an increase in farmers' interest in seeds obtained using TPS technology [9].

Initially, tubers obtained from TPS seedlings were considered a promising alternative to seed tubers in potato production technology in Egypt. This was due to the fact that planting seedlings in the desert on irrigated lands in the winter period brought a good income, because the crop was exported to European countries at a good price. The mechanization of planting seedlings has reduced the cost of producing marketable potatoes. TPS seeds could be used for winter planting because they reached their physiological age [16].

\section{A. Research objective}

The aim of the research is to establish the dependence of the yield of tuberous reproductions of potatoes on the technique of growing seedlings.

\section{MATERIALS AND RESEARCH METHODS}

The scheme of experience included two options:

\section{1) A field-seeded method of obtaining seedlings - control. \\ 2) A transplanting method of obtaining seedlings.}

The experiments were laid out in 2013-2015 in the collection section of the department of agriculture and plant growing at the Student Scientific and Production Center. The study objects were the first and second tuberous reproduction of the hybrid generative progeny of the Nikulinsky and Breeze varieties. The repetition of the experiment is 6-fold. The plot allocation is randomized. Each plot included 25 plants planted in one row. An accounting area of plot was $5.25 \mathrm{~m}^{2}$.

Phenological observations were carried out directly in the field environment, accounting and data processing - in the laboratory of the department of agriculture and crop production. The aerial portion of potato plants was estimated by their height. The structure of the bush during harvesting was determined by the following indicators: the total number 
of tubers, the mass of tubers from a bush (total and marketable). Tubers with a diameter of more than $35 \mathrm{~mm}$ are considered marketable.

\section{RESEARCH RESULTS AND DISCUSSION}

Measurement of plant height was carried out 5 times with an interval of two weeks. The measurement results showed that the plants of the first tuber reproduction during the entire growing season in the variant with the transplanting method of obtaining seedlings were $2-3 \mathrm{~cm}$ higher than the plants of the control variant. So, the height of the plants of the control variant averaged $31.2 \mathrm{~cm}$, in the variant with the transplanting method of obtaining seedlings $-34.4 \mathrm{~cm}$ at the time of the third measurement in the middle of the growing season. A similar pattern was observed in plants of the second tuber reproduction. However, the plants of the second tuber reproduction of both variants turned out to be lower than the plants of the first tuber reproduction. The plants of the second tuberous reproduction of the control and experimental variants measured on the same day had a height of 28.1 and $30.9 \mathrm{~cm}$, respectively.

The development of the underground mass of potato plants, depending on the method of obtaining seedlings, was determined by the following indicators:

- the number of tubers from the bush;

- the mass of tubers from the bush;

- average tuber weight;

- yield;

- marketability.

Data on the number of tubers are presented in table 1 and 2. It can be seen from the tables that the maximum yield of tubers from a plant for all the years of research was obtained with a variant of a transplanting method of growing seedlings. On average, 11.6 tubers were obtained for three years from one bush on the first tuber reproduction in the experimental variant, while in the control variant their number was 10.2. The plants of the second tuber reproduction formed a smaller number of tubers in both variants. The variant with a transplanting method of obtaining seedlings is superior to control on the mass of tubers from a bush. As can be seen from tables 3 and 4, the weight of tubers from a bush for an average of three years was $507 \mathrm{~g}$ on the first tuber reproduction in the control variant, in the experimental version of $100 \mathrm{~g}$ more $-607 \mathrm{~g}$. In the second tuber reproduction, the figures are lower - 433 and $550 \mathrm{~g}$, respectively.

The results on the average weight of the tuber are presented in Table 5 and 6 . The transplanting method of obtaining seedlings allowed increasing the average weight of the tuber. So, an increase to control was $5 \mathrm{~g}$ in the first tuber reproduction, and in the second - $4 \mathrm{~g}$.
TABLE I. THE NUMBER OF TUBERS FROM A BUSH, PIECES

\begin{tabular}{|l|c|c|c|c|}
\hline \multirow{2}{*}{ Option } & \multicolumn{4}{|c|}{ first tuberous reproduction } \\
\cline { 2 - 5 } & $\mathbf{2 0 1 3}$ & $\mathbf{2 0 1 4}$ & $\mathbf{2 0 1 5}$ & $\begin{array}{c}\text { Average } \\
\text { over 3 years }\end{array}$ \\
\hline $\begin{array}{l}\text { Control - field- } \\
\text { seeded }\end{array}$ & 10.3 & 10.1 & 10.1 & 10.2 \\
\hline Transplanting & 11.9 & 11.7 & 11.2 & 11.6 \\
\hline
\end{tabular}

TABLE II. THE NUMBER OF TUBERS FROM A BUSH, PIECES

\begin{tabular}{|l|c|c|c|c|}
\hline \multirow{2}{*}{ Option } & \multicolumn{4}{|c|}{ second tuberous reproduction } \\
\cline { 2 - 5 } & $\mathbf{2 0 1 3}$ & $\mathbf{2 0 1 4}$ & $\mathbf{2 0 1 5}$ & $\begin{array}{c}\text { Average } \\
\text { over 3 } \\
\text { years }\end{array}$ \\
\hline $\begin{array}{l}\text { Control - field- } \\
\text { seeded }\end{array}$ & 9.4 & 8.3 & 8.0 & 8.6 \\
\hline Transplanting & 10.6 & 10.0 & 9.5 & 10.0 \\
\hline
\end{tabular}

TABLE III. THE MASS OF TUBERS IN THE BUSH, G

\begin{tabular}{|l|c|c|c|c|}
\hline \multirow{2}{*}{ Option } & \multicolumn{4}{|c|}{ first tuberous reproduction } \\
\cline { 2 - 5 } & $\mathbf{2 0 1 3}$ & $\mathbf{2 0 1 4}$ & $\mathbf{2 0 1 5}$ & $\begin{array}{c}\text { Average } \\
\text { over 3 years }\end{array}$ \\
\hline $\begin{array}{l}\text { Control - field- } \\
\text { seeded }\end{array}$ & 632 & 181 & 709 & 507 \\
\hline Transplanting & 804 & 201 & 817 & 607 \\
\hline
\end{tabular}

TABLE IV. THE MASS OF TUBERS IN THE BUSH, G

\begin{tabular}{|l|c|c|c|c|}
\hline \multirow{2}{*}{ Option } & \multicolumn{4}{|c|}{ second tuberous reproduction } \\
\cline { 2 - 5 } & $\mathbf{2 0 1 3}$ & $\mathbf{2 0 1 4}$ & $\mathbf{2 0 1 5}$ & $\begin{array}{c}\text { Average } \\
\text { over 3 } \\
\text { years }\end{array}$ \\
\hline $\begin{array}{l}\text { Control - field- } \\
\text { seeded }\end{array}$ & 581 & 139 & 578 & 433 \\
\hline Transplanting & 719 & 181 & 749 & 550 \\
\hline
\end{tabular}

TABLE V. AVERAGE TUBER WEIGHT, G

\begin{tabular}{|l|c|c|c|c|}
\hline \multirow{2}{*}{ Option } & \multicolumn{4}{|c|}{ first tuberous reproduction } \\
\cline { 2 - 5 } & $\mathbf{2 0 1 3}$ & $\mathbf{2 0 1 4}$ & $\mathbf{2 0 1 5}$ & $\begin{array}{c}\text { Average } \\
\text { over 3 years }\end{array}$ \\
\hline $\begin{array}{l}\text { Control - field- } \\
\text { seeded }\end{array}$ & 66 & 53 & 76 & 65 \\
\hline Transplanting & 77 & 54 & 80 & 70 \\
\hline
\end{tabular}

As for the yield, it was quite high (Table 7). The highest yield was obtained in the variant with the transplanting method of obtaining seedlings, and superiority is observed throughout the entire period of research. The average increase 
in the tuber yield of the first tuber reproduction in the experimental variant was $4.8 \mathrm{t} /$ ha.

The marketed product yield in the first tuberous reproduction, obtained by the transplanting method of growing seedlings, was $77 \%$ for an average of three years, which is $7 \%$ above control. The increase in the second tuber reproduction also amounted to $7 \%$ (Tables 8 and 9).

TABLE VI. AVERAGE TUBER WEIGHT, G

\begin{tabular}{|l|c|c|c|c|}
\hline \multirow{2}{*}{ Option } & \multicolumn{4}{|c|}{ second tuberous reproduction } \\
\cline { 2 - 5 } & $\mathbf{2 0 1 3}$ & $\mathbf{2 0 1 4}$ & $\mathbf{2 0 1 5}$ & $\begin{array}{c}\text { Average } \\
\text { over 3 } \\
\text { years }\end{array}$ \\
\hline $\begin{array}{l}\text { Control - field- } \\
\text { seeded }\end{array}$ & 69 & 51 & 82 & 67 \\
\hline Transplanting & 74 & 52 & 86 & 71 \\
\hline
\end{tabular}

TABLE VII. YIELD OF POTATO TUBERS OF THE 1 ST TUBER REPRODUCTION, T / HA

\begin{tabular}{|c|c|c|c|c|}
\hline Option & $\mathbf{2 0 1 3}$ & $\mathbf{2 0 1 4}$ & $\mathbf{2 0 1 5}$ & $\begin{array}{c}\text { Average } \\
\text { according to } \\
\text { the methods } \\
\left.\text { (HCP }_{\mathbf{0 5}}=\mathbf{0 . 1 9}\right)\end{array}$ \\
\hline $\begin{array}{c}\text { Control - field- } \\
\text { seeded }\end{array}$ & 32.6 & 9.4 & 35.0 & 25.7 \\
\hline $\begin{array}{c}\text { Transplanting } \\
\begin{array}{c}\text { Average for } \\
\text { years (HCP } \\
\text { 0.4) }\end{array}\end{array}$ & 36.1 & 10.2 & 41.3 & 30.5 \\
\hline
\end{tabular}

TABLE VIII. MARKETABILITY, $\%$

\begin{tabular}{|c|c|c|c|c|}
\hline \multirow{2}{*}{ Option } & \multicolumn{4}{|c|}{ first tuberous reproduction } \\
\cline { 2 - 5 } & $\mathbf{2 0 1 3}$ & $\mathbf{2 0 1 4}$ & $\mathbf{2 0 1 5}$ & $\begin{array}{c}\text { Average } \\
\text { over 3 years }\end{array}$ \\
\hline $\begin{array}{c}\text { Control - field- } \\
\text { seeded }\end{array}$ & 83 & 42 & 86 & 70 \\
\hline Transplanting & 89 & 50 & 91 & 77 \\
\hline
\end{tabular}

TABLE IX. MARKETABILITY, $\%$

\begin{tabular}{|c|c|c|c|c|}
\hline \multirow{2}{*}{ Option } & \multicolumn{4}{|c|}{ second tuberous reproduction } \\
\cline { 2 - 5 } & $\mathbf{2 0 1 3}$ & $\mathbf{2 0 1 4}$ & $\mathbf{2 0 1 5}$ & $\begin{array}{c}\text { Average } \\
\text { over 3 } \\
\text { years }\end{array}$ \\
\hline $\begin{array}{c}\text { Control - field- } \\
\text { seeded }\end{array}$ & 85 & 50 & 92 & 76 \\
\hline Transplanting & 94 & 61 & 95 & 83 \\
\hline
\end{tabular}

\section{CONCLUSION}

The production of more developed plants of tuberous reproductions is facilitated by the preliminary cultivation of seedlings in protected ground conditions for 40-50 days. The transplanting method of obtaining seedlings of potato plants from seedless one is characterized by an increase in yield structure indicators and an increase in the yield of tubers.

\section{REFERENCES}

[1] Mefodiev G.A. "Seed multiplication system of potato with its generative reproduction", Bulletin of the Russian Academy of Agricultural Sciences, 2003, No. 5, p. 32-33.

[2] Mefodiev G.A., Eliseeva L.V., Kokurkina O.T. "Peculiarities development of plants features of the first tuber generation, depending on the size of the planting tubers of potatoes", Modern problems of science and education, 2015, No. 1-1, P. 1699.

[3] Perl A., Aviv D., Galun E. "Protoplast-fusion-derived cms potato cybrids: potential seed-parents for hybrid, true-potato-seeds", Journal of heredity, 1990, Vol. 81, No. 6, p. 438.

[4] Ortiz R., M. golmirzaie A. "Genetic parameters for agronomic characteristics. I. Early and intermediate breeding populations of true potato seed." Hereditas, 2003, 139, No. 3. pp. 212-216.

[5] Pallais, N. "True Potato Seed: changing potato propagation from vegetative to sexual", HortScience, 1991, Vol. 26 - pp. 239-241.

[6] Pallais, N. "True potato seed quality", Theoretical and Applied Genetics, 1987, Vol. 73(6), pp. 784-792.

[7] Wiersema, S.G. \& R. Cabello. "Comparative performance of differentsized seed tubers derived from true potato seed", American Potato Journal, 1986, Vol. 63, pp. 241-249.

[8] Chujoy, E., \& Cabello, R. "The Canon of Potato Science: 29. True Potato Seed (TPS)”, Potato Research, 2007, 50(3-4), pp. 323-325.

[9] Simmonds NW. "A review of potato propagation by means of seed, as distinct from clonal propagation by tubers”, Potato Research, 1997, pp. 191-214

[10] Jagesh Kumar Tiwari; Satish K. Luthra; Vinod Kumar; Vinay Bhardwaj. "Genomics in True Potato Seed (TPS) Technology: Engineering Cloning Through Seeds", The Potato Genome, 2017, pp. $297-305$.

[11] Wattimena, G., B. McCown \& G. Weis. "Comparative field performance of potatoes from microculture", American Potato Journal, 1983, Vol. p. 27 - 33.

[12] Wiersema, S.G. "A method of producing seed tubers from true potato seed", Potato Research, 1986, Vol. 29 - pp. 225- 237.

[13] Almekinders, C. J. M., Chujoy, E., \& Thiele, G. "The Use of True Potato Seed as Pro-poor Technology: The Efforts of an International Agricultural Research Institute to Innovating Potato Production", Potato Research, 2009, Vol. 52(4), pp. 275-293.

[14] Bofu S, Yu QD, Vander Zaag P. "True potato seed in China, past, present and future", American Potato Journal, 1987, pp. 321-327

[15] Malagamba, P., "Potato production from true seed in tropical climates", HortScience, 1988, Vol. 23 - pp. 495-500.

[16] Engels, C., El Bedewy, R., \& Sattelmacher, B. "Seed tuber production from true potato seed (TPS) in Egypt and the influence of environmental conditions in different growing periods", Potato Research, 1993, Vol. 36(3), pp. 195-203. 